\title{
原著
}

\section{鼻骨骨折治療におけるエコー使用の現状 一当院及び関連施設の勤務医アンケートを通して一}

\author{
芦田 直毅 ${ }^{1)}$, 前田 陽平 ${ }^{2)}$, 秋田佳名子 ${ }^{1)}$, \\ 端山 昌樹 ${ }^{2)}$, 津田 武 ${ }^{2)}$, 猪原 秀典 ${ }^{2)}$, \\ 神原 留美 ${ }^{1)}$ \\ ${ }^{1)}$ 市立吹田市民病院耳鼻咽喉科 \\ ${ }^{2)}$ 大阪大学大学院医学系研究科耳鼻咽喉科・頭頸部外科学
}

鼻骨骨折は日常診療で耳鼻咽喉科医がよく経験する疾患であり, 徒手整復が広く行われている。しかしどの 程度正確に整復できているかの判断は医師の主観となるため, その評価が難しい症例も経験する。近年, 整復 の程度を簡便かつ客観的に評価する方法として超音波検查（以下エコーと省略）の利用が報告されているが， 一般的な手技となっていないのが現状である。今回, 大阪大学附属病院耳鼻咽喉科・頭頸部外科関連施設に勤 務する耳鼻咽喉科勤務医に対してアンケート調査を行い，鼻骨骨折診療の現状について検討した。

関連病院勤務医 121 名に対するアンケート調査で, 61 名から回答を得た。整復前後の評価にエコーを用いて いる医師は 9 名であった。整復後に画像評価を行わない医師は 50 名に上り，その主な理由として 35 名が「外観 での評価で十分である」と回答した。一方，整復に自信が持てていない医師が 43 名（70\%）と高率であった。 エコーを用いた整復について，28名（46\%）の医師が知らないと回答した。

市立吹田市民病院耳鼻咽喉科でエコーを用いた整復の経験のある医師に対し追加でアンケート調査を行い, 7 名の医師から回答を得た。7名中 6 名が自身にとって整復におけるエコーは有用と回答し, 全員が経験の少な い医師に有用と考えていた。転勤後もエコー使用経験のある医師は4名であった。

エコーを用いた鼻骨骨折整復の認知度が上昇することで，医師が自信をもってより正確に整復できるように なることを期待する。

キーワード : 鼻骨骨折, 徒手整復, エコー, アンケート調査

\section{Questionnaire for Otolaryngologists on Treatment of Nasal Bone Fracture Using Ultrasonography}

\author{
Naoki Ashida $^{1)}$, Yohei Maeda ${ }^{2)}$, Kanako Akita $^{1)}$, Masaki Hayama ${ }^{2)}$, \\ Takeshi Tsuda', Hidenori Inohara ${ }^{2)}$, Rumi Kambara ${ }^{1)}$ \\ ${ }^{1)}$ Department of Otorhinolaryngology, Suita Municipal Hospital \\ ${ }^{2)}$ Department of Otorhinolaryngology-Head and Neck Surgery, \\ Osaka University Graduate School of Medicine
}


Nasal bone fracture is a common disease in otolaryngology, and is usually treated by closed reduction. In many cases, surgical outcomes are subjectively assessed by visual inspection by physicians. In recent years, ultrasonography (US) has been shown to be useful for diagnosis and objective surgical assessment of nasal bone fracture, but this approach is still not widespread. To examine this issue further, we conducted a questionnaire on management of nasal bone fracture among otolaryngologists at Osaka University Hospital and its related facilities. The questionnaire was sent to 121 doctors, and 61 responded. Of the respondents, 9 used US for assessment of outcomes of reduction procedures, but 50 did not perform an objective examination after reduction. The main reason was that 'it is sufficient to assess reduction by visual inspection only', which was given by 35 doctors, but 43 doctors (70\%) also did not feel fully confident in their assessment of outcomes of reduction. In addition, 28 doctors (46\%) did not know that US could be used in management of nasal bone fracture. We then conducted the questionnaire for doctors who used US in reduction of nasal bone fracture at Suita Municipal Hospital. Of the seven doctors that responded, 6 thought that US is useful for management of reduction of nasal bone fracture, and 4 had used US after transfer to another hospitals. We hope that increased awareness of evaluation of nasal fracture reduction using US will make physicians more confident in their ability to perform more accurate restorations.

Key words : Nasal bone fracture, Closed reduction, Ultrasonography, Questionnaire

(2020年 6 月 28 日受稿, 2020 年 10 月 20 日受理)

\section{はじめに}

鼻骨骨折は顔面骨骨折の中でも最も頻度が高い ${ }^{1)}$ 。 我々耳鼻咽喉科医が日常診療でしばしば遭遇する疾患で あり，外観の変形を伴うものや鼻閉の原因となるものは 整復術の適応となる。整復の成否は術者の主観で判断さ れるところが大きく, 小さく薄い鼻骨を数 $m m$ 単位で整 復する必要があるため手技には熟練を要する。

従来の視診·触診に基づく整復手技を補う手段として, エコーを用いる方法が近年多く報告されている ${ }^{2 \sim 6)}$ 。当科 でも以前からエコー下整復を施行しており，滝本らが音 響カプラーゲルパッドを用いたエコー下整復術の有用性 を報告した ${ }^{5)}$ 。エコー下整復は術中リアルタイムに整復 の程度を客観的に評価できるため整復の正確性が向上 し，また整復前後のエコー所見を提示できるために患者 の安心・満足度も向上すると考える。しかし，エコー使 用の普及程度に関する報告はそしい。今回, 大阪大学耳 鼻咽喉科・頭頸部外科関連施設の耳鼻咽喉科医師にアン ケートを行い, 鼻骨骨折診療の現状と認識について調査 したので報告する。また我々市立吹田市民病院耳鼻咽喉 科でのエコーを用いた鼻骨骨折整復について紹介する。

\section{当科での鼻骨骨折整復の方法}

鼻骨骨折の診断は視診・触診と CT, エコーを用いて 行っている。整復は基本的に局所麻酔下, 希望があれば
全身麻酔下で行っている。まず鼻粘膜に $4 \%$ リドカイン・ アドレナリン含ガーゼを留置し, 塗布麻酔を行う。音響 カプラーゲルパッド*を鼻背に置き, それを通してエコー で骨折部を確認した後，ワルシャム鉗子・ランゲンベッ ク骨膜起子で用手的に整復を行う。視診に加えエコーで も鼻骨のラインを確認し，整復が不十分な部分をエコー 下に再度整復する。最後に本人に仕上がりを鏡で確認し

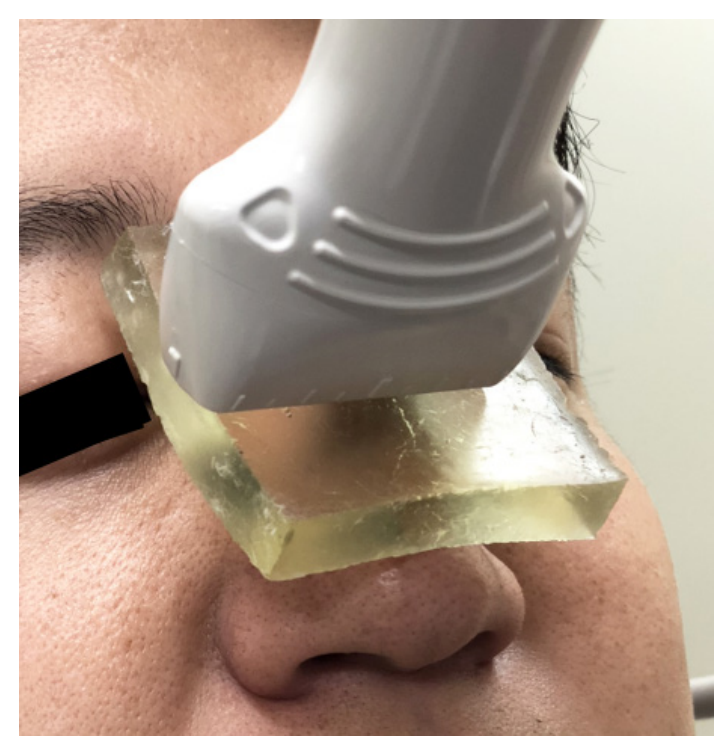

図 1

ソナゲルパッドを用いたエコーでの鼻骨の描出。初心 者でも鮮明に鼻骨のラインを描出可能である。 
$A$ 整復前CT所見

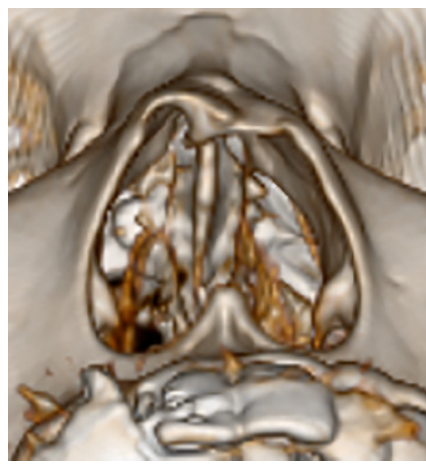

B 整復前工コ一所見

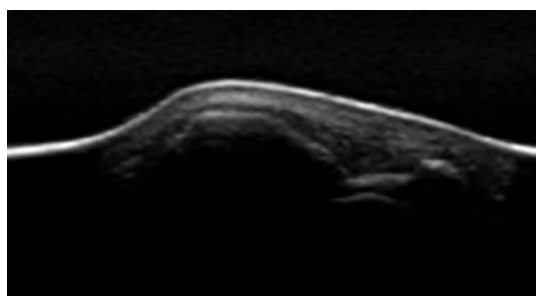

\section{C 整復後工コ一所見}

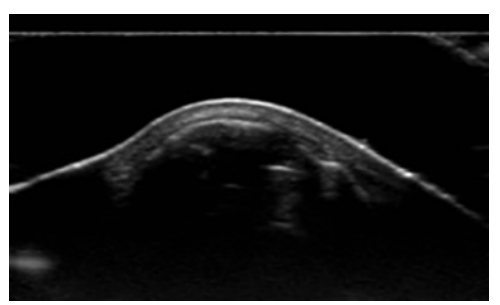

図2 画像所見。

$\mathrm{A}$ ：整復前の3D-CT所見， B : 整復前のエコー所見， C : 整復後のエコー所見。

てもらい, 同意を得られれば鼻内に軟膏ガーゼを留置し 終了としている。

実際の症例を示す。症例 : 38 歳 女性。歩行時に走行 中の自転車と衝突し受傷した。エコー・CTで鼻骨骨折を 認め, 徒手整復を行った。図 2 に整復術前の3D-CT, エ コー所見，整復術後のエコー所見を示す。術直後は鼻根 の腫脹が著明で評価が困難であったが, 術後 1 週間で腫 脹は消失し, 変形が改善していることを確認した。

※当科ではタキロン社（現タキロンシーアイ社）のソ ナゲルパッドを使用しているが, 同商品は現在販売され ていない。同様の商品が八十島プロシード社, 日本BXI 社等から販売されている。

\section{アンケート調査方法}

1) アンケート 1

大阪大学耳鼻咽喉科・頭頸部外科, 及びその関連施 設の耳鼻咽喉科勤務医を対象に, 鼻骨骨折診療の現状 · 認識に関するアンケート調査を行った。アンケートは Creative Survey社のWebアンケートツールを用いて作 成した。2015年 10 月から 2016年 2 月の間に回答を依頼

し, 施設名, 医師名共に無記名の調査とした。設問は以 下の通りである。

(1)耳鼻咽喉科経験年数

(2)専門医資格の有無

(3)鼻骨骨折整復の経験の有無

(4)鼻骨骨折の診断・評価のための画像評価はどのよう に行っているか（以下から選択：CT, レントゲン, エコー。複数選択可)

(5)整復の評価に画像検査を行っているか。行っている 場合, その方法（以下から選択：CT, レントゲン, エコー, その他)
(6) (5)でいいえと回答した場合，画像検査を行わない理 由（以下から選択：外観で十分評価できるため, CT. レントゲンでの被曝リスクのため, コスト，その他） (7)十分に整復できたか自信が持てているか（以下から 選択：しばしば自信が持てないことがある，時々自 信がもてないことがある，以前には自信がもてない ことがあった，以前から常に自信を持って整復でき ている)

(8)整復をエコーで評価する方法があるということを 知っているか

2) アンケート 2

当科で鼻骨骨折のエコー下整復を習得し, その後異動 となった勤務医に，エコー下整復への認識と異動後の診 療状況に関して追加アンケートを行った。アンケートは メールで送付, 回答を依頼した。設問は以下の通りである。

(1)当科勤務時, 鼻骨骨折の整復にエコーを用いていた か（以下から選択: 常に, 時々, 用いていなかった)

(2)自身にとって，鼻骨骨折の整復にエコーは有用と考 えるか（以下から選択：非常に有用，まずまず，ど ちらかと言えば，以前は有用であった，あまり有用 と言えない)

(3)鼻骨骨折整復の経験が少ない医師にとって, 鼻骨骨 折の整復にエコーは有用と考えるか（以下から選 択：非常に有用，まずまず，どちらかと言えば，あ まり有用と言えない)

(4)当院退職後, 鼻骨骨折の整復にエコーを用いたこと があったか。また，現在使用しているか（以下から 選択：常に用いている，時折，用いたことがある， 用いていない)

(5)(4)で「常に用いている」以外を回答した場合，そ の理由（以下より選択：1. 時間がない, 2 . 面倒, 


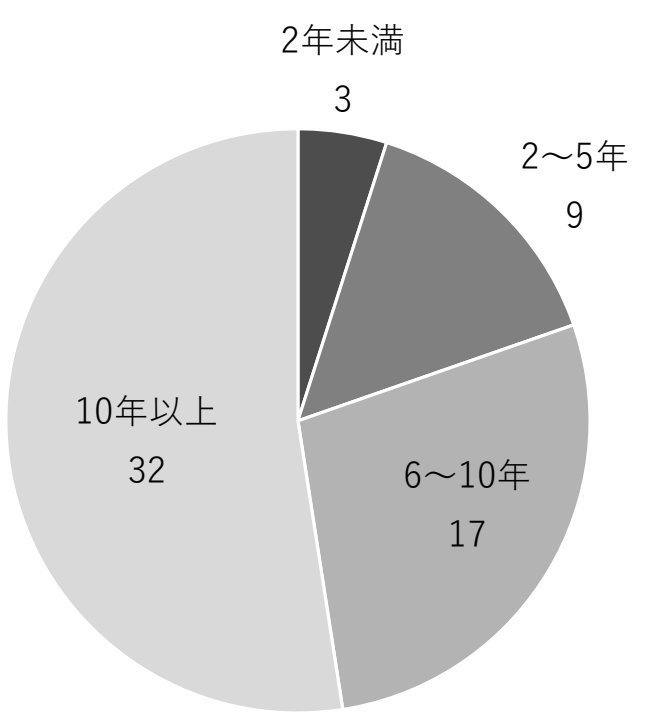

図3 アンケート 1 回答者の耳鼻咽喉科経験年数 (人)

3. 設備がない, 4. エコーなしでも十分整復できる,

5. あまり有用性を感じない，5，その他。複数回答 可，その他の場合自由回答)

(6)5で「あまり有用性を感じない」と回答した場合, その理由

(7)エコーを用いた鼻骨骨折整復を他の医師（特に経験 の少ない医師）に勧めるか（以下ょり選択：強く勧 める，どちらかと言えば勧める，あまり勧めない， 全く勧めない)

\section{解 析}

アンケート1の質問(7)にいての解析は,「しばしば自 信が持てないことがある」と「時々自信がもてないこと がある」を自信なし群，「以前には自信がもてないこと があった」と「以前から常に自信を持って整復できてい る」を自信あり群として，非専門医と専門医，エコーの

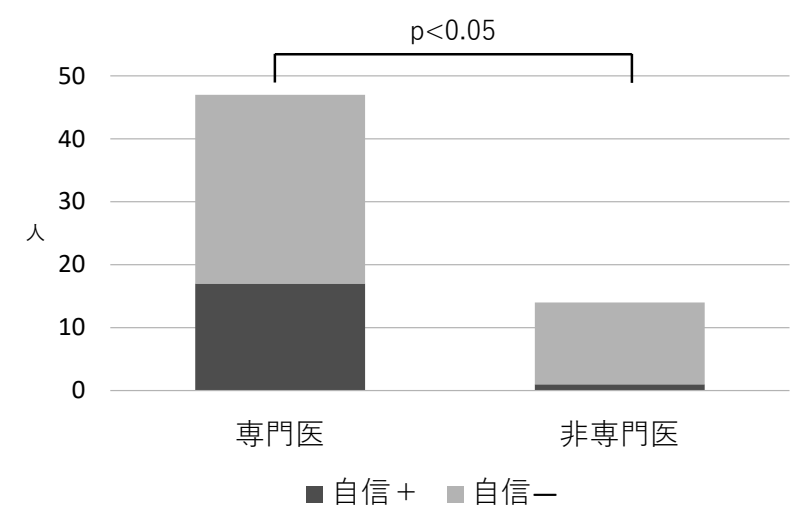

図4 整復の自信の有無と専門医・非専門医の比較。自身の 整復に自信がある医師は，専門医で有意に多かった。
経験ありとなしでMicrosoft Excel 2016を用いてカイ2乗 検定を行った。

\section{結果}

1) アンケート 1

対象は 120 名で，そのうち 61 名（50.8\%）から有効回 答を得た。耳鼻咽喉科経験年数の分布は図 3 の通りであ り, 専門医 47 名, 非専門医 14 名であった。回答者全員, 鼻骨骨折治療の経験を有していた。鼻骨骨折の診断・評 価のための画像評価は, CT61名 $(100 \%)$, 単純X線検査 (以下レントゲンと省略) 12 名 (19.7\%), エコー8名 (13.1\%) であった。整復後の評価に画像検査を行う医師は 11 名 $(18 \%)$ ，行わない医師は 50 名 $(82 \%)$ であった。行うと 答えた医師のうち，使用するモダリティはエコー9名 (14.8\%), CT3名 $(4.9 \%)$, レントゲンと回答した医師は いなかった。行わないと答えた医師のうち，その理由は 「外観での評価で十分」35名，「コストがかかる」21名， 「被爆のリスク」18名,「その他」2名であった。「その他」 の意見には，「患者が希望しない」，「整復の目的が完全修 復ではなく外観改善のため」との意見が含まれていた。 十分整復できたか自信が持てているかに関しては,「しば しば自信が持てないことがある」14名（23.0\%），「時々 自信がもてないことがある」 29 名 $(47.5 \%)$ ，「以前には 自信がもてないことがあった」 12 名 $(19.7 \%)$ ，「以前か ら常に自信を持って整復できている」6名（9.8\%）とい う結果であった。エコーで整復の評価を行う方法がある という事を認知している医師は33名 $(54.1 \%)$, 知らない 医師は 28 名 $(45.9 \%$ ）であった。

鼻骨骨折整復について，非専門医に比較し専門医に整 復に自信を持っている者が有意に多かった（ $\mathrm{p}=0.037 ）$ (図4)。一方エコーの経験ありとなしで，整復の自信に 差は認めなかった（p=0.79）（図5）。

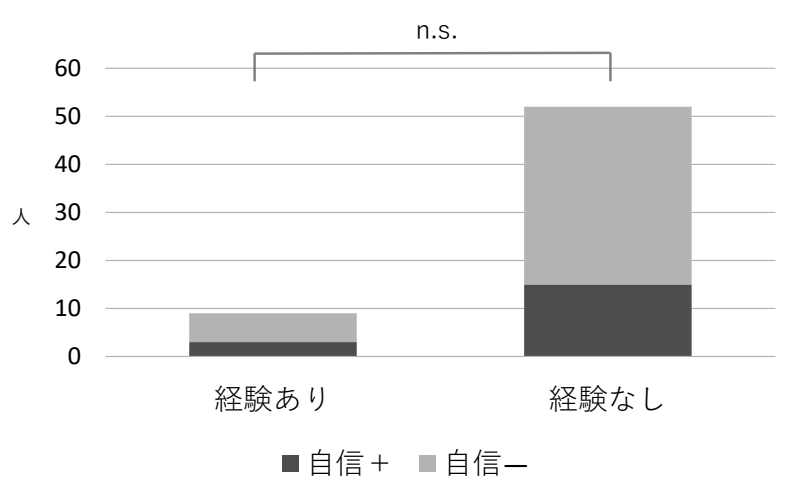

図5 整復の自信の有無とエコー経験の有無の比較。エコー 経験の有無と整復の自信に有意な関連は認めなかった。 
表 1 アンケート2の結果

\begin{tabular}{|c|c|c|c|c|c|c|c|}
\hline 回答者 & $\begin{array}{l}\text { 当科勤務時 } \\
\text { エコー使用 } \\
\text { の経験 }\end{array}$ & $\begin{array}{c}\text { 自身にとって } \\
\text { エコーは } \\
\text { 有用か }\end{array}$ & $\begin{array}{l}\text { 整復経験の少 } \\
\text { ない医師にエ } \\
\text { コーは有用か }\end{array}$ & $\begin{array}{l}\text { 転勤後の } \\
\text { エコー使用 }\end{array}$ & $\begin{array}{l}\text { 転勤後, 常にエ } \\
\text { コーを使用し } \\
\text { ていない理由* }\end{array}$ & $\begin{array}{l}\text { 他の医師に } \\
\text { 勧めるか }\end{array}$ & その他意見 \\
\hline 1 & 常に & 非常に有用 & 非常に有用 & 時々 & $1,3,4,6$ & 強く & $\begin{array}{l}\text { 整復前後で全く同じ断面での記録, 評 } \\
\text { 価は困難であり, 完全に客観的な指標 } \\
\text { とは言い難い。 } \\
\text { 整復の部位確認, 整復後評価に有用。 }\end{array}$ \\
\hline 2 & 常に & 非常に有用 & 非常に有用 & 時々 & 3 & 強く & $\begin{array}{l}\text { 始めに行っておくと解剖や整復の評 } \\
\text { 価についての理解が樑まる。特に乳幼 } \\
\text { 児に有用。 }\end{array}$ \\
\hline 3 & 常に & 非常に有用 & 非常に有用 & 常に & & 強く & \\
\hline 4 & 常に & それなりに & $\begin{array}{l}\text { どちらかと } \\
\text { 言えば }\end{array}$ & なし & 2 & $\begin{array}{l}\text { どちらかと } \\
\text { 言えば }\end{array}$ & \\
\hline 5 & 常に & それなりに & それなりに & なし & 6 & あまり & 異動後の症例の経験がない。 \\
\hline 6 & 常に & $\begin{array}{l}\text { どちらかと } \\
\text { 言えば }\end{array}$ & $\begin{array}{l}\text { どちらかと } \\
\text { 言えば }\end{array}$ & $\begin{array}{l}\text { 用いたこと } \\
\text { がある }\end{array}$ & 4 & $\begin{array}{l}\text { どちらかと } \\
\text { 言えば }\end{array}$ & $\begin{array}{l}\text { 整復には疼痛も伴うため, スピードを } \\
\text { 優先に考えている。 }\end{array}$ \\
\hline 7 & 時々 & $\begin{array}{l}\text { あまり有用と } \\
\text { 言えない }\end{array}$ & $\begin{array}{l}\text { どちらかと } \\
\text { 言えば }\end{array}$ & なし & $1,2,4,5$ & あまり & \\
\hline
\end{tabular}

※以下より選択, 複数回答可。1. 時間がない 2 . 面倒 3 . 設備がない 4 . 用いなくても可能 5 . あまり有用性を感じない 6. その他。

2) アンケート 2

対象は 10 名で, 7 名 $(70 \%)$ から有効回答を得た。結 果は表1の通りである。7名中 6 名が自身にとって整復に おけるエコーは有用と回答し，全員が経験の少ない医師 に有用と考えていた。転勤後もエコー使用経験のある医 師は 4 名であり，使用しない場合の理由としては「用い なくても可能」4名が最も多く,「時間がない」,「面倒」, 「設備がない」が2名ずつであった。

\section{考察}

鼻骨骨折の非観血的整復術を従来の視診・触診に加え てエコーを用いて行う方法は以前から報告されており， 有用性が示されている ${ }^{2 \sim 6)}$ 。鼻骨をより正確に描出するた めに様々な方法が試みられてきたが，当科では以前から 音響カプラーゲルパッドを採用し，その有用性を滝本ら が報告した ${ }^{5)}$ 。その他, ゼリーのみを用いる方法 ${ }^{6}$ や, ゴ ム手袋に水を満たしたものを音響カプラとして用いる方 法 $^{7.8)}$ が報告されているが, ゲルパッドを用いると初心者 でも鮮明に鼻骨を描出できるようになる。

エコーを用いる利点として，(1)術中リアルタイムに描 出しながら整復できること, (2)被曝がなく反復して行え ること，(3)エコーがあればどこでも行えること，(4)術後 にエコー所見を提示することで患者・家族の安心にもつ ながること, が挙げられる。
鼻骨骨折の診断そのものの評価としては回答した全 員がCTを挙げており，エコーやレントゲンを併用する ケースも見られた。

一方，正診率の高さから整復後の鼻骨骨折の評価にも CTを推奨する意見 ${ }^{9)}$ もあるが, 被曝や医療コストを眯念 する意見もある ${ }^{6)}$ 。今回のアンケートでも整復後に画像 検査を行わない理由として同様の意見が多かった。また 整復後にCTを撮像, 評価し再度整復を考慮することは患 者の精神的・時間的な負担も大きい。一方エコーは被曝 がなく，低コストで容易に行える方法であり整復後評価 に適していると考える。

またアンケートでは整復の評価は外観のみで十分であ ると考える医師が $46 \%$ を占めた。過去の報告でもエコー を用いた方法と従来の視触診のみでの方法で整復の成功 率に差はなかったことから視触診が最も重要であると述 べられている ${ }^{10)}$ 。かし一方で,「しばしば」，あるいは 「ときどき」整復の結果に自信が持てないことがあるとい う医師が $70 \%$ 占めた。これらの医師は整復後の状態を 客観的に評価する事ができればより自信を持って診療で きる可能性があり，エコーを用いる利点の大きい医師が 潜在的に多く存在する可能性が示唆された。整復の自信 については，専門医と比較して非専門医でそしい傾向に あり，専門医取得前の医師の整復においてはより有用か もしれない。今回の検討ではエコーの経験の有無と整復 
の自信に有意な差はなかったが，エコー経験のある医師 数が少ないため, この結果のみでエコーの有無が整復の 自信と直結しているかどうかの結論を出すことはできな い。今後経験者を増やした上で再検討し, エコー経験前 後で整復への自信がどの程度変化するかを調査したい。

上記の理由から筆者らは鼻骨骨折診療におけるエコー 使用がさらに広まることを期待する。しかし，今回のア ンケートではエコーを用いた評価方法を知っていると答 えた医師は $54 \%$ に留まっており，そもそも認知度に問題 があると考えられ，普及のため啓発が必要であると思わ れた。我々は症例数を重ねての論文報告や学会発表を継 続していきたい。

当科でエコー下での整復を習得した医師への追加アン ケートから, 7 名中 4 名の医師が転勤後もエコーを施行 していた。多忙な業務の中で準備をする時間がないとい う意見もあったが，汎用性のあるエコーがあれば施設を 問わず行えるのも大きな利点である。一度経験した医師 においては概敉肯定的な意見が多かった。

\section{結 論}

多くの医師が鼻骨骨折整復後に画像検査を行っていな い事がわかった。その理由として外見の評価で十分と考 える医師が多い一方, 整復の結果に自信を持てていない 医師が多かった。エコー下での整復は医療者側，患者側 共に利点があるがその認知度は低く，今後より一層の普 及が望ましい。

本論文の内容は第 57 回日本鼻科学会 (旭川市) におい て発表した。

本論文内容に関連して，開示すべきCOIは有しない。

\section{参考文献}

1）萩原佑亮：【耳鼻咽喉科領域の外傷をマスターする】 外傷性斜鼻, 鼻骨骨折. JOHNS 2019; 35: 573-575.

2) 田中 崇, 藤崎 純, 金子南紀子, 他：鼻骨骨折整 復固定術時における術中体表超音波検查の有用性. 超音波検查技術 2013; 38: 598-604.

3）辻本賢樹, 川北育子, 大崎健夫, 他: 鼻骨骨折整復 術における術中エコー検査の使用経験とその有用性 の検討. 形成外科 2014; 57: 1157-1163.

4）伊藤明日香, 青井則之, 山本崇弘, 他 : 鼻骨骨折整 復時，および軟膏ガーゼ扦入による内固定時におけ るリアルタイムでの超音波診断装置使用の有用性. 日頭顎顔会誌 2018; 34: 94-102.

5）滝本泰光, 丹家佐和子, 増村千佐子, 他 : 音響カプ ラーゲルパッドを用いた超音波エコー下鼻骨骨折整 復術の有用性の検討. 日耳鼻 2017; 120: 907-913.

6）岸部 幹, 斎藤 滋, 原淵保明：鼻骨骨折における 超音波エコーの有用性. 日耳鼻 2005; 108: 8-14.

7）高林宏輔：鼻骨骨折への対応. 耳喉頭頸 2018; 90: 344-346.

8）三羽英之, 秋元正宇, 櫻井 透, 他 : 術中超音波検 查を用いた鼻骨骨折整復術における「水手袋カプ ラー」の有用性. 日頭顎顔会誌 2017; 33: 83-86.

9）矢部哲司, 元村尚嗣, 村岡道德：鼻骨骨折新鮮例の 術後CT所見による評価とその必要性について. 形成 外科 1999; 42: 303-307.

10) Yabe $T$, Tsuda $T$, Hirose $S$, et al: Comparison of ultrasonography-assisted closed reduction with conventional closed reduction for the treatment of acute nasal fractures. J Plast Reconstr Aesthet Surg 2014; 67: 1387-1392. 